\title{
The European Identity Rationale in the EU Free Trade Agreements: Economic rather than Cultural Objectives?*
}

\author{
El fundamento de la identidad europea en los Tratados de Libre \\ Comercio de la UE: ¿Objetivos económicos más que culturales?
}

\author{
Maria Chochorelou \\ Becaria Pre-doctoral de Derecho Internacional Público \\ Universitat Internacional de Catalunya \\ mchochorelou@uic.es
}

doi: http://dx.doi.org/10.18543/ced-02-2019pp227-249

Summary: I. Introduction.-II. EU Competences on Culture and Trade.-III. Regulation of the audiovisual sector in EU FTAs. 1. «Cultural Exception» clauses. 2. Audiovisual provisions in Protocols of Cultural Cooperation.-IV. Regulation of other cultural sectors in EU FTAs.-V. Culturally-sensitive Chapters in EU FTAs. 1. Subsidies. 2. Intellectual Property. a. Copyright and Patents. b. Geographical Indications.-VI. Conclusion

\begin{abstract}
In recent years, we can observe an increase of the EU Free Trade Agreements (FTAs) addressing cultural matters. The focus of the Union seems to lie on the audiovisual services sector, which is excluded by the scope of all these Agreements. This so-called 'cultural exception' clause does not apply to other cultural sectors, which are however still regulated in EU FTAs. The regulation takes the form of either commitments and reservations made by the Parties to a specific sector, or cooperative provisions mainly found in the Protocols of Cultural Cooperation supplementing some EU FTAs. Although not explicitly mentioning culture, other EU FTA Chapters, such as Subsidies and Intellectual Property, also entail cultural considerations. Rhetorically, the EU has considered the inclusion of cultural aspects into its FTAs as a tool to protect and promote the European identity and cultural diversity. However, both the negotiations as well as the texts of these Agreements illustrate that the motives behind this exclusion are mainly economic and political.
\end{abstract}

Keywords: Free Trade Agreements, cultural exception, audiovisual sector, cultural identity

Resumen: En los últimos años, podemos observar un aumento de los Tratados de Libre Comercio de la UE (TLC) que abordan cuestiones culturales. La Unión

* Recibido el 2 de julio de 2018, aceptado el 16 de julio de 2018. 
presta especial atención al sector audiovisual, que está excluido del ámbito de todos los Tratados. Esta cláusula de "excepción cultural", no se aplica a otros sectores culturales, que, sin embargo, están regulados por los TLC de la UE. La regulación toma la forma de compromisos y reservas relativas a sectores concretos formuladas por las Partes, o disposiciones cooperativas que se encuentran principalmente en los Protocolos sobre Cooperación Cultural que complementan algunos TLC de la UE. Además, algunos Capítulos de TLC como los Subsidios y la Propiedad Intelectual, aunque no mencionan expresamente a cultura, también implican consideraciones culturales. Retóricamente, la UE considera la inclusión de aspectos culturales en sus TLC como un instrumento para proteger y promover la identidad europea y la diversidad cultural. Sin embargo, tanto las negociaciones como los textos de estos Tratados ilustran que los motivos de esta exclusión son también económicos y políticos.

Palabras claves: Tratados de Libre Comercio, excepción cultural, sector audiovisual, identidad cultural

\section{Introduction}

The discussion of a 'European identity' entered the public discourse in 1973, when the Copenhagen 'Declaration of European Identity' was signed. ${ }^{1}$ The underlying assumption in the Declaration was that common cultural factors were the foundations of a common identity, ${ }^{2}$ thus culture has been considered as a defining notion of European identity. Not long after the adoption of the Declaration, a debate on the existence of a European cultural identity arose. On the one hand, monoculturalists assert that Europeans share core cultural values, which are the essence of European identity. On the other hand, multiculturalists believe in cultural diversity, arguing that European cultural identities are profoundly different from one another. ${ }^{3}$ Whether a unique European cultural heritage exists or European cultural identity is in essence a compilation of those of its Member States, cultural diversity is indeed a distinctive feature of Europe, stemming from its history and rich variety of traditions.

${ }^{1}$ Declaration on European Identity of the Council of the European Union (Copenhagen: 14 December 1973).

2 Michael Bruter, "Winning Hearts and Minds for Europe: The Impact of News and Symbols on Civic and Cultural European Identity", Comparative Political Studies 36, n. ${ }^{\circ} 10$ (2003): 1153.

${ }^{3}$ Rik Pinxten, Marijke Cornelis and Robert A. Rubinstein, "European Identity: Diversity in Union", International Journal of Public Administration 30, nos 6-7, (2007): 687-688 
Since the adoption of the Declaration, the need to forge a European identity by preserving cultural diversity has become a central objective of the European Union's foreign policy. EU institutions have taken on a role of generating, expressing and promoting European identity in the international community. In other words, the EU serves as the 'exporter' of European good norms, values and culture to third parties. ${ }^{4}$ The attempt of the EU to foster cultural diversity is especially witnessed in its foreign trade policy. Historically, there has been a clash between trade and culture, which has mainly revolved around the question of whether and to what extent free trade principles should apply to different cultural products and services..$^{5}$ The debate became particularly heated during the negotiations of World Trade Organization (WTO), when cultural proponents, with the EU in the forefront, pressed for the exemption of any culture-related product or service from the WTO rules. ${ }^{6}$ Such a 'cultural exception' clause was never included in the texts of the WTO Agreements, which led the EU to embark on a different path towards addressing the trade-culture nexus; it started integrating cultural considerations into its bilateral and regional Free Trade Agreements (FTAs). Direct mentions of culture and protocols on cultural cooperation have been integrated into these FTAs. However, these policies raised concerns both with regard to the competence of the EU to regulate on cultural matters, as well as regarding the rationale behind the integration of such issues into FTAs, with academics and civil society doubting that the motives of the EU are purely 'cultural'.

The aim of this paper is to examine whether the EU puts forward the 'European identity' rationale in its external trade policy in order to preserve and promote this diversity or rather to extract economic benefits from cultural-related sectors. In doing so, we will first briefly retrace the history of the EU cultural policies and present the EU competences in the fields of culture and foreign affairs, reflecting on whether the Union gets

${ }^{4}$ Christian Freres, "The European Union as a Global «Civilian Power»: Development Cooperation in EU-Latin American Relations", Journal of Interamerican Studies and World Affairs 42, n. ${ }^{2}$ (2000): 64; Ian Manners, "Normative Power Europe: A Contradiction in Terms?", Journal of Common Market Studies 40, n. ${ }^{\circ} 2$ (2002): 235-258

5 Mary E. Footer and Christoph B. Graber, "Trade Liberalisation and Cultural Policy", Journal of International Economic Law 3, n. ${ }^{\circ} 1$ (2000): 1; Christoph B. Graber, Michael Girsberger and Mira Nenova, eds., Free Trade Versus Cultural Diversity: WTO Negotiations in the Field of Audiovisual Services (Zurich: Schulthess, 2004). Ivan Bernier, "Trade and Culture", in World Trade Organization: Legal, Economic and Political Analysis, ed. by Patrick F.J. Macrory, Arthur E. Appleton and Michael G. Plummer (US: Springer, 2005).

${ }_{6}$ Mira Burri, «The European Union, the World Trade Organization and Cultural Diversity», in Cultural Governance and the European Union, ed. by Evangelia Psychogiopoulou (UK: Palgrave Macmillan, 2015), 197-199 
the right to insert cultural objectives in its FTAs. In a second stage, we will analyse the texts of both older and more recently concluded EU FTAs and Cultural Cooperation Protocols, in order to identify the cultural identity considerations that appear in them and determine what the motives are for this integration. Special attention will be given to the provisions regulating the audiovisual sector. The examination of how other cultural sectors are addressed in these FTAs will follow. Finally, other culturally-sensitive FTA Chapters, such as subsidies, copyright, patents and geographical indications, will be analyzed and their impact on the promotion of cultural diversity will be assessed.

\section{EU Competences on Culture and Trade}

At its foundation in 1950 , the European Community had an economically-centred action and culture did not lie in its range of responsibilities. However, the Community's aim to integrate culture into its agenda became clear from an early stage of its function, with the first initiatives already taken in 1970. According to the European Commission, culture was an instrument to create solidarity between the Member States, which, in turn, would be vital to secure the public support that the Union needed for moves towards market and monetary integration. ${ }^{7}$ Thus, culture was already perceived by the EU as a medium through which the EU could strengthen its economic position. The absence of a formal competence to act in the area of culture raised concerns over a so-called 'democratic deficit' of the European Community to regulate in such issues. ${ }^{8}$ Despite the criticism, the EU dynamically continued its cultural policy and, in the early 1990s, one more element was added to the EU cultural initiatives: the concept of 'cultural diversity'. The will of the Community was to create strategies that would harmoniously lead to "the identification both of different cultural traditions and of common uniting principles". ${ }^{9}$ The ad hoc development of EU cultural measures did not tackle the concerns regarding the exclusive competence of the EU Member States to deal with such issues. In spite of the absence of formal recognition, though, the Economic

7 Document of the Commission of the European Communities (COM (87)603 final), A Fresh Boost for Culture in the European Community, (Brussels: Bulletin of the European Communities, 14 December 1987): 1

${ }^{8}$ Clive Barnett, "Culture, policy and subsidiarity in the European Union: From symbolic identity to the governmentalisation of culture", Political Geography 20, n. ${ }^{04}$ (2001): 414.

9 Additional Opinion, n. ${ }^{\circ} \mathrm{C} 62,26.3$, of the Economic and Social Committee, on a fresh boost for culture in the European Community (OJ, 13 March 1990), point 1.4.2 
and Social Committee claimed that "the EU's competence to act in support of culture had already been effectively established through existing features of Community action, such as the free movement of cultural goods and services and of cultural workers, the development of audio-visual policies, and various taxation measures". ${ }^{10}$

The signing of the Treaty of Maastricht (subsequently replaced by the Treaty of Amsterdam) was supposed to mitigate the abovementioned concerns, as, for the first time in history, it endowed the EU with legally binding cultural competences. Article 151(1) of the Treaty on European Union (TEU) stated that "The Community shall contribute to the flowering of the cultures of the Member States, while respecting their national and regional diversity and at the same time bringing the common cultural heritage to the fore [...] The Community shall take cultural aspects into account in its action under other provisions of this Treaty." However, paragraph 5 of the same Article gave to the European Parliament and the Council, after consulting the Committee of the Regions, only incentive powers, while it did not allow the decisionmaking for the harmonisation of the laws and regulations of the Member States. Therefore, this provision introduced a 'principle of subsidiarity', allowing the EU to only support and supplement the Member States' cultural actions when and if only this was necessary. ${ }^{11}$ At the same time, Article 151.4 contained an integration principle, reading: "The Community shall take cultural aspects into account in its action under other provisions of this Treaty, in particular in order to respect and to promote the diversity of its cultures". This provision rendered culture a horizontal interest or, to put it another way, the rules governing sectors which concern economy and trade could be deemed to be part of the European Union's cultural policy. ${ }^{12}$ This clause could partly justify the introduction of cultural objectives into the EU FTAs. The entry into force of the Lisbon Treaty did not change much, as the content of the Article 151 was directly transferred to the new Treaty (Article 167 of the Treaty on the Functioning of the European Union - TFEU). From the reading of the Article it seems that the EU competences on cultural issues are marginal. However, in order to conclude whether the introduction of cultural objectives in the EU FTAs is acceptable, we also need to examine the EU primary law on the competences on foreign commercial policy.

\footnotetext{
10 Ibidem, 26-36.

11 Alessandro Chechi, "Cultural Matters in the Case Law of the European Court of Justice", Art Antiquity and Law 9, n. ${ }^{03}$ (2004): 284

12 Ibidem, 284-285
} 
The origins of the so-called "perennial disputes over trade and culture" 13 in multilateral trading system lie already in the Uruguay round of negotiations, which resulted in the establishment of WTO in 1995. During these negotiations, the EU defended a 'cultural exception' clause, which would exclude cultural products and services from General Agreement on Tariffs and Trade (GATT) and General Agreement on Trade in Services (GATS), approach entirely contradicting the liberalization of cultural industries that the US sought. The goal of the EU was only partially met; although the Union adopted a wide range of exemptions from the WTO's Most Favored Nation principle for the audiovisual sector and made no liberalization commitments, neither GATT nor GATS contain any specific reference to cultural policies. The involvement of the EU in the WTO negotiations was a result of the exclusive EU competence in external trade policy, which was conferred to the EU by Article 133 of the Treaty establishing the European Community (TEC). However, Article 133.6 TEC provided for an explicit carve-out for cultural services, providing that agreements which include provisions regarding cultural services fall within the shared competence of the EU and its member States. Thus, decisions for mixed trade and cultural agreements in the Council needed to be taken by unanimity. ${ }^{14}$ It seems that the EU Commission played a big role in the adoption of such agreements. Member States agreed upon the participation of the Commission in the negotiations of the United Nations Educational, Scientific and Cultural Organization Convention on the Protection and Promotion of the Diversity of Cultural Expressions (UNESCO Convention). The UNESCO Convention was considered as an efficient instrument against the trade regime and an important balance to the WTO regime, ${ }^{15}$ and its ratification by the EU Commission in 2005 legitimized the EU's actorness in the external trade policy area. The adoption of the Lisbon Treaty somehow altered the situation. In an attempt to simplify the procedures, Article 207 TFEU stipulates that EU trade policy is an exclusive EU

13 Craig Van Grasstek, "Treatment of cultural goods and services in international trade agreements" in Trends in audiovisual markets: Regional perspectives from the South, ed. by G. Alsonso Cano, (Paris: UNESCO, 2006), 93-97

${ }^{14}$ Markus Krajewski, "External trade law and the constitution treaty: Towards a federal and more democratic common commercial policy", Common Market Law Review 42 (2005): 95-97; Sophie Meunier and Kalypso Nicolaïdis, "The European Union as a trade power", in International relations and the European Union ed. by Christopher Hill, Michael Smith and Sophie Vanhoonacker (UK: Oxford University Press 2005), 257.

15 Antonios Vlassis and Lilian Richieri Hanania, "Effects of the CDCE on trade negotiations" in Cultural Diversity in International Law: The Effectiveness of the UNESCO Convention on the Protection and Promotion of the Diversity of Cultural Expressions ed. by Lilian Richieri Hanania (New York: Routledge 2014), 26 
competence for all sectors, including mixed agreements. The specificity of cultural services remains acknowledged in Article 207 TFEU, albeit in a different form; paragraph 4(3a) states that "the Council shall also act unanimously for the negotiation and conclusion of agreements ... in the field of trade in cultural services, where these agreements risk prejudicing the Union's cultural and linguistic diversity." This last sentence is quite problematic, as neither the concept of cultural diversity is defined nor does the Treaty give details on when a risk should be considered imminent or who should judge on whether there is such risk. ${ }^{16}$ Moreover, some States and civil society feared that the EU would misuse the Lisbon Treaty to incorporate culture in its FTAs by the back door, while cultural matters are primarily a policy domain of the EU Member States. ${ }^{17}$ The Lisbon rules on the division of competences had an impact on EU external trade policy. Both for the implementation of the UNESCO Convention in its external relations, and due to the fact that the cultural debate was not solved on the multilateral level, the EU started integrating cultural objectives either directly into its FTAs or by concluding Protocols on Cultural Cooperation as parts of these FTAs. As the next Sections will illustrate, these FTA provisions were mainly focused on the audiovisual sector, but other cultural sectors were also regulated.

\section{Regulation of the audiovisual sector in EU FTAs}

The audiovisual sector has been considered as a peculiar-to-regulate sector, especially due to "the fact that it has both economic components as well as social and cultural ones" ${ }^{18}$ The EU has always seen the audiovisual sector as one of the most influential vehicle of cultural identity, ${ }^{19}$ thus has sought to "safeguard Member States' cultural prerogatives". ${ }^{20}$ Provisions on the audiovisual sector are found in all existing EU FTAs, however, the EU policy is twofold; while most of the treaties introduce the so-called

16 Jan Loisen and Ferdi de Ville, "The EU-Korea Protocol on Cultural Cooperation: Toward Cultural Diversity or Cultural Deficit?", International Journal of Communication 5 (2011): 258-259

17 Ibidem, 255

18 Background Note by the WTO Secretariat (S/C/W/310) on Audiovisual Services (12 January 2010), para. 2.

${ }_{19}$ Colloquy of the Council of Europe in cooperation with the French Minister of Culture and Communication and the City of Strasbourg, on 'European Culture: Identity and Diversity' (Strasbourg: 8 - 9 September 2005), 7

${ }^{20}$ Evangelia Psychogiopoulou, "The External Dimension of EU Cultural Action and Free Trade: Exploring an Interface”, Legal Issues of Economic Integration 41 (2014): 66. 
'cultural exception' clause, some others, supplemented by Protocols on Cultural Cooperation, include cooperative or 'preferential treatment' provisions.

\section{1. 'Cultural exception' clauses}

As highlighted by the European Commission, the audiovisual sector has a clear place among sensitive sectors that should be covered by the cultural exception. ${ }^{21}$ This is why, the most common EU policy has been to employ an exemption mechanism, allowing for the exclusion of the audiovisual sector from the scope of the agreements. This so-called 'cultural exception' clause takes aim at the mitigation of trade liberalization through trade restrictive measures. Particularly, foreign audiovisual providers are not allowed to access the EU market and they do not have the right to be treated the same as their EU counterparts. Therefore, EU Member States are free to discriminate against them. ${ }^{22}$ The first EU FTA to include such clause was the EU-Chile FTA, which entered in force in February 2003. Despite the Agreement's pledges for greater audiovisual cooperation among the Parties, audiovisual services are entirely excluded from the scope of the Chapter on Trade in Services ${ }^{23}$ approach that was then taken in all EU FTAs. The older EU FTAs were concluded with developing countries, where the stronger negotiating power of the Union made easier the introduction of the so-desired 'cultural exception' clause in the treaties. This has not been the case during the negotiations with strong economies. Examples that deserve to be addressed separately are the recently concluded Comprehensive Economic and Trade Agreement (CETA) and the still being negotiated Transatlantic Partnership on Trade and Investment (TTIP).

In CETA, the Parties adopted a unique model of 'cultural exception'. Its uniqueness lies in its asymmetric scope of application. More specifically, while the Canadian cultural clauses cover in general the "cultural industries", the EU again excludes only the audiovisual sector. The concept of "cultural industries" is defined in CETA Article 1.1 broadly covering the publishing, audiovisual and musical industries. On the other hand, the term "audiovisual sector" is not defined, creating uncertainty for its content. Moreover, the cultural clause does not apply to the Agreement in its entirety, but only grants

${ }^{21}$ Memo, n. ${ }^{\circ}$.13-363, of the European Commission, "European Commissioner for Trade Karel De Gucht on the Transatlantic Trade and Investment Agreement: The Cultural Exception is Not Up for Negotiation!" (Brussels: 22 April 2013), 1

22 Document $n .^{\circ} 152670$ of the EU Commission on TTIP and Culture (16 July 2014): 2

${ }^{23}$ EU-Chile FTA Articles 39 and 95.2(b) respectively. 
exceptions in five Chapters of the Agreement, namely the ones of Crossborder Trade in Services, Subsidies, Investment, Domestic Regulation and Government Procurement. ${ }^{24}$ The reason why the EU did not opt for cultural exceptions that cover all sectors of the Agreement is that, according to the Union, governments "have more interests than the protection of all products that are testimony to a country's culture. Economic growth ... and many other policy goals are also of concern to them". ${ }^{25}$ The justification of the Union shows that, besides the preservation of the cultural identity of the EU Member States, the special focus on the audiovisual sector does not only have cultural motives, but the rationale is also economic.

The 'cultural exception' has been also ambivalent during the negotiations of the TTIP Agreement and two divergent positions were highlighted. On the one hand, for some EU Member States the exclusion of the sector was a non-negotiable point. Especially the French government affirmed that the cultural exception principle is a constituent part of the European identity, which protects the Union's diversity and vitality. ${ }^{26}$ On the other hand, other Member States, such as the UK, disagreed on this exclusion, arguing that this would weaken the negotiating power of the EU. ${ }^{27}$ In June 2013, the EU Council met and, after several hours of negotiations, reached a consensus on the exclusion of the audiovisual services from the mandate given to the EU Commission. The consensus on the audiovisual exception was considered a big success, especially by those that feared the harmful economics effects of a possible penetration of the US entertainment industry in the EU market. ${ }^{28}$ However, some critics argued that this exclusion might not be enough. The Committee on Culture and Education argued that the TTIP could still pose severe risks to cultural diversity in Europe and suggested the adoption of a general 'audiovisual

${ }^{24}$ CETA articles 7.7, 8.2 and 8.9,9.2, 12.2 and Annex 19-7 respectively.

25 Study of the European Parliament's Directorate-General for Internal Policies (Policy Department B: Structural and Cohesion Policies), "Research for Cult Committee-Culture and Education in CETA" (EU: 19 December 2016), 36-37

${ }^{26}$ Communication of the French Ministry of Culture on Transatlantic partnership/cultural exception, "EU deal on cultural exception «a victory for France»" (Paris, 17 June 2013), accessed on 18 February 2018, https://uk.ambafrance.org/EU-deal-on-cultural-exception-a

27 Antonios Vlassis, "European Commission, trade agreements and diversity of cultural expressions: Between autonomy and influence", European Journal of Communication 31, n. 4 (2016): 452-3

28 Valentina Vadi and Bruno de Witte, eds., Culture and International Economic Law (New York: Routledge, 2015), 107-108; Tobias Theiler, "Why the European Union Failed to Europeanize Its Audiovisual Policy", in Constructing Europe's Identity: The External Dimension, ed. by Lars-Erik Cederman (US and London: Lynne Rienner Publishers, 2001), $117-135$ 
exception' clause, which would cover all chapters of the treaty and would be based in technological neutrality. ${ }^{29}$

\section{Audiovisual provisions in Protocols of Cultural Cooperation}

After the adoption of the UNESCO Convention, the EU negotiated two Protocols on Cultural Cooperation with two countries within a short timeframe. In 2008, it signed a Protocol with the CARIFORUM countries, which was included in the respective Economic Partnership Agreement (EPA). Two years later, a Protocol with the Republic of Korea was signed and included in the final text of the 2011 EU-Korea FTA. According to the Commission, these Protocols were a tool to "ensure that the audiovisual sector is dealt with through cooperation provisions and therefore not covered by trade provisions in the Services and Establishment Titles of the agreements". 30 Both the EU-CARIFORUM EPA and the EU-Korea FTA stick to the 'cultural exception' approach, however, their Protocols follow a different pathway in the EU's external audiovisual policy. As mandated by the UNESCO Convention, they call the Parties to "cooperate to foster the development of a common understanding and enhanced exchange of information on cultural and audio-visual matters through a dialogue". ${ }^{31}$ The sectoral cooperation provisions of the two Protocols are similar but not identical. They both state that the Parties "shall endeavour to facilitate the use of international and regional standards in order to ensure compatibility and interoperability of audiovisual technologies", the "rental and leasing of the technical material and equipment, such as radio and television equipment, musical instruments and studio recording equipment, necessary to create and record audiovisual works" and the "digitalization of audiovisual archives". ${ }^{32}$ Moreover, they call for the promotion of audiovisual works "through the organisation of festivals, seminars and similar initiatives". ${ }^{33}$ These provisions, although contributing

${ }^{29}$ Draft Opinion, n. ${ }^{\circ}$ 2014/2228(INI), of the European Parliament's Committee on Culture and Education, on recommendations to the European Commission for the Committee on International Trade on the negotiations for the Transatlantic Trade and Investment Partnership (TTIP), (6 February 2015), 3.

30 Argumentaire of the European Commission on the Title on Cultural Cooperation in future EU trade agreements (11 May 2007):1, accessed on 19 February 2018, http://trade. ec.europa.eu/doclib/docs/2007/may/tradoc_134655.pdf

31 EU-CARIFORUM Protocol Article 2.2; EU-Korea Protocol Article 2.2

${ }^{32}$ EU-CARIFORUM Protocol Articles 5.3, 5.4 and 5.5; EU-KOREA Protocol Articles 6.3, 6.4 and 6.5.

${ }^{33}$ EU-CARIFORUM Protocol Article 5.2; EU-KOREA Protocol Article 6.1 
to the strengthening of cultural exchanges, use a soft language which does not impose binding obligations on States.

The most important clauses are arguably the ones granting 'preferential treatment' to the State-partner, foreseen by article 16 of the UNESCO Convention. Both Protocols state that "the Parties shall encourage the negotiation of new and implementation of existing co-production agreements between one or several Member States of the European Union" and the signatory Party. ${ }^{34}$ The 'co-production' provisions were seen by the EU as a framework to implement its Audiovisual Media Services Directive, which "provides for enhanced cultural diversity through allowing the extension of the status of European works to audio-visual works coproduced with third countries". ${ }^{35}$ The EU-CARIFORUM Protocol provides for the qualification of the EU-CARIFORUM co-productions as European works under the Audio-visual Media Services Directive, meaning that they would benefit from the quotas that applied to the European productions. However, the Protocol sets up quite restrictive criteria relating to ownership, control, nationality and States' contribution for a work to be considered as a co-produced work. ${ }^{36}$ Also, it is worth noting that this preferential treatment is non-reciprocal and would become reciprocal only if "preferential schemes for the promotion of local or regional cultural content are established by one or more Signatory CARIFORUM States". ${ }^{37}$ Turning to the EU-Korea Protocol, this instrument also provides for co-productions which would qualify as European works and would be "entitled to benefit from EU Party scheme for the promotion of local/regional cultural content" for a renewable period of three years. But contrary to the EU-CARIFORUM Protocol, this right is reciprocal. ${ }^{38}$ This Protocol adds to the - already stringent - EU-CARIFORUM Protocol's conditions for the qualification of a work as 'co-produced' ${ }^{39}$ In order to ensure the fulfillment of these criteria, it also provides that the co-produced films should be submitted to a "technical check" procedure ${ }^{40}$ Furthermore, the EU-Korea Protocol sets up a special Committee on Cultural Cooperation to assess the results of the implementation of the co-production provisions, assisted by Domestic

${ }^{34}$ EU-CARIFORUM Protocol Article 5.1; EU-KOREA Protocol Article 5.2

35 Background paper of the European Commission on the Protocol on Cultural Cooperation with Korea' (March 2009), accessed on 19 February 2018, http://trade.ec .europa. eu/doclib/docs/2009/march/tradoc_142541.pdf

${ }^{36}$ EU-CARIFORUM Protocol Article 5.2(a)

37 EU-CARIFORUM Protocol Article 5.2(c)

38 EU-KOREA Protocol Articles 5.3, 5.4 and 5.5

39 EU-KOREA Protocol Article 5.6

40 EU-KOREA Protocol Article 5.1, fn 1. 
Advisory Groups ${ }^{41}$ Finally, contrary to the EU-CARIFORUM Protocol, the EU-Korea Protocol provides for a dispute settlement procedure. ${ }^{42}$

This EU way of approaching the audiovisual sector was controversial. During the EU-CARIFORUM FTA negotiations, the mandate given from the EU Council to the EU Commission was to entirely exclude the audiovisual sector from the treaty. However, the Commission widely interpreted this mandate ${ }^{43}$ and concluded the Protocol, which gave the audiovisual sector a cooperative dimension. Because of the timing of the negotiations with the adoption of the UNESCO Convention and the clear development perspective of the Protocol, even the most skeptical EU Member States accepted its conclusion. Despite the consensus climate, the Protocol raised concerns especially because of the fact that the negotiations were conducted by trade negotiators and not by cultural experts. ${ }^{44}$ Critics also believed that by integrating cultural concerns into trade negotiations, culture was made subordinate to trade and - as a consequence- a tool towards to the achievement of the economic objectives of the Union. ${ }^{45}$ At the other end of the spectrum, the EU-Korea Protocol was not concluded under the same political tolerance. During the negotiations, some European professional organizations submitted a letter to the EU Commission arguing that both the way the Protocol was negotiated as well as its content would "bring culture and audiovisual back into trade negotiations", ${ }^{46}$ which would consequently put at risk the promotion of cultural diversity. They also doubted whether the Protocol could satisfyingly implement the UNESCO Declaration, saying that the Declaration "favors autonomous discussions" in the field of culture, hence the negotiations of such a Protocol should be disconnected from the negotiations of the trade Agreement. Despite the reactions, the EU Commission adopted a Protocol with a strong approach

${ }^{41}$ EU-KOREA Protocol Articles 5.8(a)(b) and 5.9.

${ }^{42}$ EU-KOREA Protocol Article 3BIS (b).

43 Xavier Troussard, Valerie Panis-Cendrowicz and Julien Guerrier, "Preferential Treatment for Developing Countries", The UNESCO Convention on the Protection and Promotion of the Diversity of Cultural Expressions - Explanatory Notes, ed. by Sabine Schorlemer and Peter-Tobias Stoll (London: Springer 2012), 446.

44 Antonios Vlassis, "L'Union européenne, acteur international de la diversité culturelle? Le protocole de cooperation culturelle", InaGlobal (2010): 3,4, http://hdl.handle. net $/ 2268 / 176765$

${ }^{45}$ Lilian Richieri Hanania, "Cultural Diversity and Regional Trade Agreements - The European Union Experience with Cultural Cooperation Frameworks", Asian Journal of WTO \& International Health Law and Policy 7, n. ${ }^{\circ 2}$ (2012): 443

46 Letter of European Coalitions for Cultural Diversity (Brussels, 7 May 2009), accessed on 16 February 2018, http://www.filmdirectors.eu/wp-content/uploads/2009/11/Letter-Eur.organisations-FTA-EU-Korea-7.5.091.pdf 
of market access in the audiovisual sector. ${ }^{47}$ This can be explained by the fact that, at the time, Korea represented a strategic partner for the EU. The EU-Korea Protocol was considered by the opponents as a "bargaining chip for use in trade negotiations". ${ }^{48}$ The strength of Korea's audiovisual sector contributed to the opposition; it was feared that the Protocol would be detrimental to the European cultural industries and especially the animation sector, as the Korean productions could penetrate the EU market. ${ }^{49}$

\section{Regulation of other cultural sectors in EU FTAs}

As seen above, the only sector exempted by the EU FTAs through the 'cultural exception' clause is the audiovisual. This resulted in the terms 'culture' and 'audiovisual' being considered by some authors as largely synonymous in the context of the trade and culture debate. ${ }^{50}$ Nevertheless, the term 'culture' indicates a broader coverage..$^{51}$ As the EU Commission suggested in its TTIP report, 'culture' also includes: performing arts, music, new media, book publishing, architecture, cultural heritage, press, advertising, video games, graphic and fashion design. ${ }^{52}$ Most of the EU FTAs include provisions relating to these sectors, which generally aim to preserve the ability of the States to regulate. However, the discretion given to the States varies considerably from one FTA to another. ${ }^{53}$

The most common way of the EU to address cultural matters in its FTAs is by drawing up specific commitments, the so-called 'positive list' method. This bottom-up approach means that the States remain unbound by the trade concessions of the Agreement, unless they explicitly inscribe a certain sector in a schedule of commitments. Examples of older EU FTAs using this method are the EU-Chile, the EU-Colombia/Peru, the EU-CARIFORUM and the EU-Korea FTAs. Newly concluded Agreements, such as the EU-Singapore and the EU-Vietnam FTAs also set up a positive list of commitments. The commitments made by

47 Hanania, "Cultural Diversity and Regional...", 444

48 Loisen and de Ville, "The EU-Korea Protocol on...", 264

49 Ibidem, 262

50 Footer and Graber, "Trade Liberalization and Cultural Policy", 119.

51 Bregt Natens, "A Comparative Analysis of Audio-Visual Services in Selected U.S. and Japanese Regional Trade Agreements: Lessons for the European Union", Legal Issues of Economic Integration 41, n. ${ }^{3}$ (2014): 13

52 EU Commission, "TTIP and Culture", 1

53 Véronique Guèvremont and Ivana Otašević, Culture in Treaties and Agreements: Implementing the 2005 Convention in Bilateral and Regional Trade Agreements (Paris: UNESCO, 2017), 21 
the EU Member States differ both with regards to the cultural sector and to the extent of commitment. The sectors that the States have been more willing to progressively liberalize were the News and Press Agencies Services and the Sporting Services. The Entertainment Services (including theatre, live bands, circus and discotheque services) was also subject to a significant degree of liberalization, while most EU Member States refrained from undertaking commitments relating to Libraries, Archives, and Museums. ${ }^{54}$ Interestingly, in CETA, the EU deviated from the abovementioned method and adopted the - usually preferred by Canada - 'negative list' approach. This approach starts from the reverse; all cultural sectors are in principle fully open to competition and bound from the non-discrimination provisions of the Agreement, and the States indicate the sectors on which they wish to make reservations. With these reservations the States aim to reserve their right to introduce new cultural measures which do not conform to the FTA. ${ }^{55}$ In CETA, all EU Member States entered a reservation on Recreation, cultural and sporting services providing for the non-application of the market access provisions for cross-border trade in services and investment. Several reservations have also been recorded for the entertainment services, including theatre, live bands and circus services and Library, archives and museums and other cultural services. The sector with the least reservations was again the Publishing and printing sector. ${ }^{56}$

While both approaches aim at the market-opening of the cultural sectors, there are several differences between them, notably concerning their regulatory transparency and their impact of trade liberalization on culture. The 'positive list' approach offers States more flexibility in adapting their commitments. It allows States to select the sectors that they wish to expose to the free market, and leaves the extent of this progressive liberalization at their discretion. However, it cannot offer the same protection as the one that would be afforded by an 'exception' clause. It limits the regulatory ability of the governments, making it difficult for them to adopt new measures in the cultural sectors covered by their commitments and policies which do not conform to the rules of the FTA. ${ }^{57}$ The "negative list' approach has been criticized to entail an even greater risk for States

${ }^{54}$ EU-Chile FTA Annex VII No. 7; EU Colombia/Peru FTA Annex VII-Section B No. 15, Annex VIII-Section B No. 10 and Annex IX; EU-CARIFORUM EPA Annex IV-A No 15 and Annex IV-B No. 10; EU-Korea FTA Annex 7-A-1 No. 10 and Annex 7-A-2 No. 15; EUSingapore FTA Appendix 8-A-1 No. 10, Appendix 8-A-2 No. 15 and Appendix 8-A-3 No. 15; EU-Vietnam FTA Annex 8-a No. 15, Annex 8-b No. 15 and Annex 8-c No. 10

55 EU Parliament, "Research for Cult Committee-Culture and Education in CETA", 20.

56 CETA Annexes I and II

57 Guèvremont and Otašević, Culture in Treaties and Agreements..., 22-23 
seeking to secure their regulatory freedom, as, aside from a certain number of specific reservations, the cultural sectors are entirely liberalized. Hence, it involves the greatest degree of market-opening..$^{58}$ One second cluster of criticism had to do with the fact that all commitments or reservations focus on cultural services, whilst cultural goods are left without protection. ${ }^{59}$ The EU has, however, argued that these concerns are unwarranted, as the support required for cultural goods is largely effectuated through EU or EU Member State subsidies (see next Section). ${ }^{60}$ Moreover, the protection accorded to certain cultural sectors was not considered sufficient and the lack of a general exception clause for all cultural sectors was condemned. However, the EU did not seem to believe that every cultural sector needed protection. Especially with regards to the News and Press Agency Services sector the Commission alleged that it "is very competitive and seeks to gain access to the markets of other countries" ${ }^{61}$ again projecting the economic dimension of cultural industries.

Besides the binding provisions, the EU FTAs supplemented by the Protocols on Cultural Cooperation further include 'soft-law' clauses on cultural matters. The Protocols were the first instruments to contain one or more explicit references to the UNESCO Convention in their preambles. They pursue the objective of capacity building and define a cooperative framework which would facilitate the exchange of cultural activities, goods, and services. For example, they provide for preferential treatment, which involve the temporary entry and stay of artists and other cultural professionals. ${ }^{62}$ These cooperation provisions of these Protocols refer to cultural sectors, such as performing arts, publications, and the protection of cultural heritage sites and historical monuments. ${ }^{63}$ In the new-generation EU FTAs the cultural cooperation provisions were eliminated. CETA is the only exception; in its preamble, it underlines the right of the Parties "to preserve, develop and implement their cultural policies, to support their cultural industries for the purpose of strengthening the diversity of cultural expressions and to preserve their cultural identity". A similar text was also proposed by the EU to be used

58 Gilbert Gagne, The Trade and Culture Debate: Evidence from US Trade Agreements (London: Lexington Books, 2016), 31

59 Alexandre L. Maltais, "Cultural exceptions", in Making Sense of the CETA. An analysis of the Final Text of the Canada-European Union Comprehensive Economic and Trade Agreement, ed. by Scott Sinclair, Stuart Trew and Hadrian Mertins-Kirkwodd (Ottawa: Canadian Centre for Policy Alternatives, 2014), 49-55, accessed on 21 February 2018, https:// www.policyalternatives.ca/publications/reports/making-sense-ceta;

${ }^{60}$ EU Parliament, "Research for Cult Committee-Culture and Education in CETA", 38

${ }^{61}$ EU Commission, "TTIP and Culture", 4

62 EU-CARIFORUM Protocol Article 3; EU-Korea Protocol Article 4

${ }^{63}$ EU-CARIFORUM Protocol Articles 7, 8 and 9; EU-Korea Protocol Articles 8, 9 and 10. 
in the preamble of TTIP. ${ }^{64}$ Despite this preambulatory language, CETA does not invite the Parties to cooperate on cultural matters.

\section{Culturally-sensitive Chapters in EU FTAs}

Some EU FTA Chapters, while not always explicitly contain cultural clauses, are nevertheless connected to the objectives and principles of the UNESCO Convention and may affect the objective of protection of cultural diversity. The most culturally-sensitive Chapters are the ones on Subsidies and Intellectual Property.

\section{Subsidies}

A cultural subsidy is a direct payment furnished by a government to its cultural industries, which aims to ensure that some public policy purpose in is preserved or promoted. Certain areas of culture are heavily subsidized by the EU Member States and they can survive only because they are publically funded. The regulation of subsidies has for long been a sensitive matter in international trade relations ${ }^{65}$ The WTO and, more particularly, the Agreement on Subsidies and Countervailing Measures provides for a set of rules, according to which some categories of subsidies are prohibited, while others are in principle permitted, unless they adversely affect the interests of other Members. ${ }^{66}$

The older EU FTAs did not include detailed provisions on subsidies. However, most of them explicitly exempted subsidies from the scope of application of the entire Chapters on Trade in Services, Establishment and Economic Commerce. ${ }^{67}$ This exemption does not directly mention culture, however, it should be considered as cultural-friendly, as it allows EU Member States to freely subsidize cultural sectors. The newly concluded EU FTAs are stricter, limiting or prohibiting the use of subsidies. Although these FTAs in principle still exempt subsidies from the scope of their Chapters on Trade in Services, ${ }^{68}$ the hard conditions placed on their Subsidies Chapters would

${ }^{64}$ EU Commission, "TTIP and Culture", 3

65 Jingxia Shi, Free Trade and Cultural Diversity in International Law (UK: Hart Publishing Ltd., 2013), 150-151

${ }_{66}$ WTO Agreement on Subsidies and Countervailing Measures Articles III, V, VIII

67 EU-Chile FTA Article 95.4, EU-CARIFORUM FTA Article 60.3, EU-Korea FTA Article 7.1(3)

${ }^{68}$ EU-Colombia/Peru FTA Article 107.3; CETA Article 9.2(2g); EU-Singapore FTA Article 8.1(2a); EU-Vietnam FTA Chapter 8-1, Article 1.4(t) 
make it more difficult to achieve cultural promotion objectives. The only two new-generation FTAs that explicitly refer to cultural issues in their Chapters on Subsidies are the CETA and the EU-Vietnam FTA. CETA Article 7.7 states that "nothing in this Agreement applies to subsidies or government support with respect to audio-visual services for the European Union...", thus again only focusing on the audiovisual sector. The EU-Vietnam FTA Article x.1 of the Chapter 11-II on Subsidies says that "subsidies can be granted by a Party when they are necessary to achieve a public policy objective" and explicitly lists "promoting culture and heritage conservation" as one of these public policy objectives. This final provision keeps the essence of protection of cultural diversity, however the other new-generation EU FTAs do not achieve that. Critics have alleged that the lack of a provision clearly protecting cultural subsidies could render the EU's internal policy and legislation on subsidies legally questionable and distortive of competition. ${ }^{69}$ The EU disagreed and argued that the Chapters on Subsidies will not affect the ability of the EU Member States to discriminate against foreign suppliers and provide financial support to their own cultural industries..$^{70}$ Criticism was also expressed with regards to the lack of a clause exempting subsidies from the scope of the Chapters on Trade to Goods. This should not be considered as problematic, if we consider that all the recent EU FTAs reaffirm the rights and obligations of a Party under the WTO Agreement. ${ }^{71}$ Thus, the GATT Article III.8(b) which allows "the payment of subsidies exclusively to domestic producers" is also applicable to these FTAs.

\section{Intellectual Property}

Culture and Intellectual Property (IP) are inextricably linked. Cultural works embody exquisite creativity and are of cultural and historical value to both their producers and the society. ${ }^{72}$ One way to protect tangible and intangible cultural expressions is by granting to those creators Intellectual Property rights. The Intellectual Property domains that seem more relevant to the cultural discussion are the copyright and patent protection, as well as the geographical indications.

69 Jochen Kürten and Emiliy Sherwin, «Trading culture for TTIP?», Deutsche Welle, 15 July 2014, accessed on 23 February 2018, http://www.dw.com/en/trading-culture-for-ttip/a17786723

70 EU Commission, "TTIP and Culture", 5

71 EU-Singapore FTA Article 12.6; CETA Article 7.8

72 Molly Torsen and Jane Anderson, Intellectual Property and the Safeguarding of Traditional Cultures: Legal Issues and Practical Options for Museums, Libraries and Archives (Geneva: WIPO, 2010), 2 


\section{a. Copyright and Patents}

In the context of the copyright and patent protection, the notion of 'cultural exception' could be conceived of differently by the public and by persons engaged in the cultural sector. Users request free access to cultural goods, while cultural producers wish to strengthen IP rights. This issue is even more prominent in the digital age and the concept of 'cultural exception' should be revived taking into account the current developments in the sectors of information, communication and technology..$^{73}$

The inclusion of IP references was only sporadically seen in early EU FTAs. The first EU FTA to introduce more detailed provisions was the EU-Colombia/Peru FTA, followed by the CETA, the EU-Singapore FTA and the EU-Vietnam FTA. The only Agreement that explicitly mentions the IP-culture linkage is the EU-Colombia/Peru FTA, whose Article 196.3 states: "the Parties recognise the need to maintain a balance between the rights of intellectual property holders and the interest of the public, particularly regarding ... culture ...". In addition, its Article 197.7 talks of "the impact of information and communication technologies on the usage of literary and artistic works, artistic performances, phonogram productions and broadcasts and, therefore, the need to provide adequate protection of copyright and related rights in the digital environment", provision that nonetheless uses a soft language without imposing obligations to the States. New-generation EU FTAs dedicate a whole Chapter on IP rights, whose provisions are, though, not identical. With regards to copyright, CETA and the EU-Singapore FTA maintain the TRIPS Agreement's standard of 50 years of protection, ${ }^{74}$ while the EUColombia/Peru FTA and the EU-Singapore FTA extend it to 70 years. ${ }^{75}$ Regarding the patent protection, CETA alters significantly the TRIPS content; although it maintains the TRIPS patent duration of 20 years, its Article 20.27 provides for a patent term adjustment which would compensate for delays occurring during their registration, therefore de facto lengthens their protection. Moreover, CETA Article 27.4 gives the patent holders a right to appeal, which makes it easier for them to maintain market exclusivity for their patents. According to the EU Commission, these provisions aim to protect 'Europe's innovators and

${ }^{73}$ Marlen Bartsch, "The Return of the Cultural Exception and its Impact on International Agreements", Global Media Journal 1, n.04 (2014): 3

${ }_{74}$ TRIPS Part II, Section I, Article 12; CETA Article 20.3(1) and 20.7; EU-Vietnam FTA Chapter 12 Article 4.7(1).

${ }^{75}$ EU-Colombia/Peru FTA Article 218.1; EU-Singapore FTA Art. 11.5(4). 
artists' ${ }^{76}$ However, they fail to address the abovementioned objective of the EU-Colombia/Peru FTA, namely to balance the rights of IP right holders and the interest of the public on cultural issues. A good way to achieve this balance would be the one suggested in the EU Commission's proposal for a new EU Copyright Directive: the inclusion of a mandatory exception to the IP protection, which would "permit cultural heritage institutions to reproduce works and other subject-matter permanently in their collections for preservation purposes, for example to address technological obsolescence or the degradation of original supports". ${ }^{77}$

\section{b. Geographical Indications}

In recent years, Geographical Indications (GIs) have been considered to be particularly useful for the protection of traditional cultural expressions. ${ }^{78}$ The EU Commission supports this position advocating that GIs are a "key to EU ... cultural heritage, traditional methods of production and natural resources" ${ }^{79}$ The EU Regulation No 1151/2012 also states that their protection can make "a major contribution to (the Union's) living cultural and gastronomic heritage" ${ }^{80}$ At the international level, GIs are legally regulated in the TRIPS Agreement, which provides a two-tier system for their protection. Article 22 establishes a basic level of protection, while Article 23 provides an enhanced level of protection for wines and spirits. During the EU negotiations, the EU demanded the enhanced protection of Article 23 TRIPS to be extended also to agricultural and foodstuff products, as well as the establishment of a

${ }^{76}$ Fact Sheet of the European Commission on CETA - a trade deal that sets a new standard for global trade (Brussels: 29 October 2016), accessed 1 March 2018, http://europa. eu/rapid/press-release_MEMO-16-3580_en.htm

77 Proposal n. . 2016/0280 (COD), of the EU Commission for a Directive of the European Parliament and of the Council on copyright in the Digital Single Market, COM(2016) 593 final, (Brussels: 14 December 2016): 16, para 20.

78 Daphne Zografos, "Can Geographical Indications Be a Viable Alternative for the Protection of Traditional Cultural Expressions?" in New Directions in Copyright Law, Volume 3, ed. by Fiona Macmillan and Kathy Bowrey (Cheltenham: Edward Elgar, 2006), 39; Anselm Kamperman Sanders, "Incentives for Protection of Cultural Expression: Art, Trade and Geographical Indications", Journal of World Intellectual Property 13 (2010): 82; Dev S. Gangjee, "Geographical Indications and Cultural Heritage", The WIPO Journal 4, n. ${ }^{\circ} 1$ (2012): 85

79 Memo n. ${ }^{\circ}$ 03/160 of the European Commission, "Why Do Geographical Indications Matter to Us?" (Brussels, 30 July 2003), accessed on 2 March 2018, http://europa.eu/rapid/ press-release_MEMO-03-160_en.htm

${ }^{80}$ Regulation (EU) n. $.^{\circ} 1151 / 2012$, of the European Parliament and of the Council, of 21 November 2012, on quality schemes for agricultural products and foodstuffs, L 343/1 (OJ, L 343/1, 14 December 2012): recital (1). 
multilateral system of notification and registration of GIs. ${ }^{81}$ These goals were not achieved, thus the Union sought to pursue a stronger protection through its FTAs. The approach that the EU embraced was to include in these FTAs clauses that "should as far as possible offer identical levels of $I P$ protection to that existing in the EU', ${ }^{82}$ thus to apply its sui generis GI protection system. ${ }^{83}$ This application has not always been easy, due to the different nature of the respective protection systems in the different countries. (sui generis vs. trademark). ${ }^{84}$

The first EU trade Agreement to regulate GIs was the EUCARIFORUM EPA. Its Article 145 should be considered as the first successful attempt of the EU to extend the higher standards of protection of wines and spirits to agricultural products and foodstuffs. Moreover, the treaty explores the relationship between GIs and trademarks; although it grants prevalence to the former in the cases that the two categories conflict, it also proposes criteria which enable their coexistence. ${ }^{85}$ However, the EU did not achieve its goal to impose its sui generis system in this Agreement. Subsequent FTAs were made more comprehensive dedicating a whole Section on GIs. In most of these treaties, the EU achieved a high level of protection for its most significant commercially products, extending the enhanced protection of TRIPS to agricultural products and foodstuffs. ${ }^{86}$ The only FTA which did not entirely reach this goal was the EU-Colombia/ Peru FTA, which only provides for a weak protection of GIs, but leaves a door open for the future adoption of strong-form protection for both wines/ spirits and foodstuffs. ${ }^{87}$ With or without 'TRIPS-plus' provisions, all FTAs draft lists of GIs that are accorded special protection, which, as we can observe, are always much longer for the EU than for the other State partner

${ }^{81}$ Communication $\mathrm{n} .{ }^{\circ} \mathrm{WT} / \mathrm{GC} / \mathrm{W} / 547$, of the EC to the WTO, on Geographical Indications (14 June 2005)

${ }^{82}$ Communication from the Commission, "A Single Market for Intellectual Property Rights Boosting Creativity and Innovation to Provide Economic Growth, High Quality Jobs and First Class Products and Services in Europe", COM(2011) 287 Final (24 May 2011): para. 3.6.2.

${ }^{83}$ Quyen Dao, "Geographical Indications in European Union-Vietnam Free Trade Agreement (EVFTA): Challenges in Implementation" (June 31, 2016): 6. Available at SSRN: http://dx.doi.org/10.2139/ssrn.3094857

${ }^{84}$ Bernard O'Connor and Laura Richardson, "The legal protection of Geographical Indications in the EU's Bilateral Trade Agreements: moving beyond TRIPS", Rivista di diritto alimentare $6, \mathrm{n}^{04}(2012): 7$

${ }^{85}$ Article 145(D)(2) EU-CARIFORUM FTA Articles 145(D)(2) and Article 145(D)(1) and (4).

${ }^{86}$ EU-Korea FTA Article 10.18; EU-Singapore FTA Article 11.6(1); EU-Vietnam FTA Article 12.6(1)

87 EU-Colombia/Peru FTA Article 210 
to the treaty. ${ }^{88}$ Furthermore, these FTAs are made more flexible, providing for the addition of further products onto the abovementioned lists ${ }^{89}$ and they establish specific institutions responsible for these additions..$^{90}$ With regards to the registration of these GIs, the EU-Korea FTA, EU-Central America, EU-Singapore and EU-Vietnam FTAs adopt the sui generis system of the EU and establish a legal policy framework similar to the one of the Union. Nevertheless, they still allow the co-existence of protected GIs and prior trademarks..$^{91}$ The transmission of the EU sui generis system has proven more difficult in CETA. However, the two State Partners have found a middle-ground solution, which, on the one hand, satisfied - at least partially - the demands of the EU to extend the protection of GIs beyond wines and spirits, while, on the other hand, preserved the trademark-based system of Canada. ${ }^{2}$

Summarizing, there seem to be discrepancies among the various EU FTAs, both in terms of the level of protection provided to GIs, as well as with regards to the specific products that are granted protection. It is hard to believe that this uneven, product-by-product protection is linked to the intention of the EU to protect cultural diversity. This approach is better comprehended if we consider the commercial and economic interests that specific GIs have in different export markets..$^{93}$

\section{Conclusion}

The culture-and-trade debate is a long-standing issue and the EU has always been a proponent of protecting its cultural identity in trade negotiations. After the failure to achieve this objective in the multilateral level, the Union has sought to introduce cultural considerations in its FTAs.

The main focus of the EU has been the audiovisual services sector, which is excluded by the scope of all its FTAs. Rhetorically, the Union

88 O’Connor and Richardson, "The legal protection of...”, 7; Hazel Moir, "Geographical Indications: An Assessment of EU Treaty Demands" in Australia, the European Union and the New Trade Agenda, ed. by Annmarie Elijah et al. (Acton: ANU Press, 2017), 131

89 EU-Korea FTA Article 10.24; EU-Peru-Colombia FTA Article 209; EU-Central America Article 247;

90 EU-Korea FTA Article 10.2; EU-Colombia/Peru Article 257.2; EU-Central America Article 247.1

91 EU-Korea FTA Article 10.21(3)(5); EU-Central America FTA Article 248.1-2; EUSingapore FTA Article 11.21(1)(2)(3)(4); EU-Vietnam FTA Article 12.6(7)

92 Alessandra Moroni, "New Generation of Free Trade Agreements: Towards 'International' European Geographical Indications (2016): 17. Available at SSRN: https:// ssrn.com/abstract $=2861481$

93 O'Connor and Richardson, "The legal protection of...", 16-17 
has supported the idea of such 'cultural exception' by relying on arguments relating to the importance of the audiovisual sector for the promotion of the European cultural identity. Nevertheless, the motives behind this exclusion seem to be mainly economic. Fearing of the domination of the American entertainment services in a free market, the EU intends to close its market to the US providers. The rationale of the protection of cultural diversity was also used during the negotiation of Protocols on Cultural Cooperation, where the audiovisual sector took a more cooperative dimension. EU Member States and civil society argued that, with the conclusion of these Protocols, the EU Commission exceeded its competences, sidestepping the mandate that was given to it by the EU Council to exclude the sector from trade negotiations. Moreover, the Protocols' clauses on co-productions and their preferential access to the EU market were criticized for being a risk for the EU economy and for rendering culture subordinate to trade.

Besides the audiovisual sector, there is no other cultural sector entirely exempted from the EU FTAs. The regulation of cultural sectors in these Agreements takes the form of commitments or reservations by the EU Member States. This approach does not offer the same level of protection as a general 'exception clause' and it leads to the progressive liberalization of these cultural sectors. From the reading of the lists of commitments and reservations, it can be inferred that the preferences of the EU Member States on which sectors deserve protection are polarized and largely depend on the State partner to the FTA, as well as the commercial interest of the particular cultural sector for each Member State. The new-generation FTAs also introduce Chapters on Subsidies and IP rights, such as copyrights and patents and GIs, which, although not explicitly referring to culture, could be linked to cultural aspects. However, they are not identical in all FTAs and this inconsistency again has to do with the political and economic circumstances under which the FTA was adopted.

The asymmetry of the cultural considerations of the EU FTAs proves that the interaction between trade and culture is a sensitive and complex issue. Both the negotiations, as well as the texts of the FTAs illustrate that the ideas of the EU Member States and the EU Institutions, as well as the EU Member States themselves, do not converge on neither the cultural sectors that deserve protection, nor the reason for this protection. In turn, this should make us reflect on both the existence of a real, common European cultural identity and the ability of FTAs to protect and promote such identity. 


\section{About the author}

Maria Chochorelou is a PhD Candidate of Public International Law at the UIC and a researcher in the Charlemagne Institute of European Studies. $\mathrm{Her} \mathrm{PhD}$ focuses on the Investor-State Dispute Settlement provisions of the new-generation Free Trade and International Investment Agreements. She graduated from the law school of the National and Kapodistrian University of Athens in 2013. In 2014 she earned her LL.M. in Public International and European Law with specialization in Trade and Investment from the University of Amsterdam. She worked as an intern in the UN Commission on International Trade Law and she is a member of the Athens Bar Association.

\section{Sobre la autora}

Maria Chochorelou es becaria pre-doctoral de Derecho Internacional Público en la UIC y investigadora del Instituto Carlomagno de Estudios Europeos. $\mathrm{Su}$ tesis doctoral se centra en el tema de las disposiciones sobre la solución de controversias entre inversores y Estados en la nueva generación de los Acuerdos de Libre Comercio y los Acuerdos Internacionales de Inversión. En 2014, se licenció en Derecho por la Universidad de Atenas. Asimismo, en 2014, obtuvo el Máster en Derecho Internacional Público por la Universidad de Ámsterdam, con especialización en comercio internacional y ley de inversiones. Ha trabajado como pasante en la Comisión de las Naciones Unidas para el Derecho Mercantil e Inversiones (CNUDMI) y es miembro de la Asociación de Abogados de Atenas. 


\section{Derechos de autor}

Los derechos de autor (para la distribución, comunicación pública, reproducción e inclusión en bases de datos de indexación y repositorios institucionales) de esta publicación (Cuadernos Europeos de Deusto, CED) pertenecen a la editorial Universidad de Deusto. El acceso al contenido digital de cualquier número de Cuadernos Europeos de Deusto es gratuito inmediatamente después de su publicación. Los trabajos podrán leerse, descargarse, copiar y difundir en cualquier medio sin fines comerciales y según lo previsto por la ley; sin la previa autorización de la Editorial (Universidad de Deusto) o el autor. Así mismo, los trabajos editados en CED pueden ser publicados con posterioridad en otros medios o revistas, siempre que el autor indique con claridad y en la primera nota a pie de página que el trabajo se publicó por primera vez en CED, con indicación del número, año, páginas y DOI (si procede). Cualquier otro uso de su contenido en cualquier medio o formato, ahora conocido o desarrollado en el futuro, requiere el permiso previo por escrito del titular de los derechos de autor.

\section{Copyright}

Copyright (for distribution, public communication, reproduction and inclusion in indexation databases and institutional repositories) of this publication (Cuadernos Europeos de Deusto, CED) belongs to the publisher University of Deusto. Access to the digital content of any Issue of Cuadernos Europeos de Deusto is free upon its publication. The content can be read, downloaded, copied, and distributed freely in any medium only for non-commercial purposes and in accordance with any applicable copyright legislation, without prior permission from the copyright holder (University of Deusto) or the author. Thus, the content of CED can be subsequently published in other media or journals, as long as the author clearly indicates in the first footnote that the work was published in CED for the first time, indicating the Issue number, year, pages, and DOI (if applicable). Any other use of its content in any medium or format, now known or developed in the future, requires prior written permission of the copyright holder. 